\title{
Age and petrology of the Kaapinsalmi sanukitoid intrusion in Suomussalmi, Eastern Finland
}

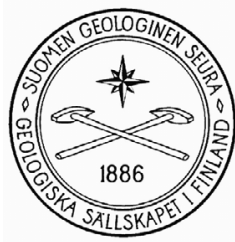

\author{
Esa Heilimo ${ }^{1) *}$, Perttu Mikkola ${ }^{2)}$ and Jahna Halla ${ }^{3)}$ \\ 1) Department of Geology, P.O. Box 64, FI-00014, University of Helsinki, Finland \\ 2) Geological Survey of Finland, P.O. Box 1237, FI-70211, Kuopio, Finland \\ 3) Geological Museum, Finnish Museum of Natural History, P.O. Box 11, FI-00014, University \\ of Helsinki, Finland
}

Short Communication

Key words: intrusions, sanukitoids, geochemistry, absolute age, U/Pb, zircon, Neoarchean, Kaapinsalmi, Suomussalmi, Finland

*Corresponding author email: esa.heilimo@helsinki.fi

\section{Introduction}

Sanukitoids (high Mg-granitoids) are a group of distinctive Neoarchean granitoids, which differ in chemical composition from the voluminous tonalite-trondhjemite-granodiorite (TTG) suite. Shirey and Hanson (1984) first introduced the term sanukitoid to refer to mantle-derived rocks, which resemble high$\mathrm{Mg}$ andesites, known as sanukites in the Miocene Setouchi belt of Japan. Stern et al. (1989) defined sanukitoid geochemistry as $\mathrm{SiO}_{2}=55-60 \%, \mathrm{MgO}$ $>6 \%, \mathrm{Mg} \#>60, \mathrm{Sr}>600-1800$ ppm, $\mathrm{Ba}>600-$ $1800 \mathrm{ppm}, \mathrm{Cr}>100 \mathrm{ppm}, \mathrm{Ni}>100 \mathrm{ppm}$ and LREE enriched compared to HREE. The term sanukitoid series has been introduced for granitoids with relatively high $\mathrm{Mg \#}, \mathrm{MgO}, \mathrm{Sr}, \mathrm{Ba}, \mathrm{Cr}$ and $\mathrm{Ni}$ at any given silica level (Lobach-Zhuchenko et al., 2005). Sanukitoids composition shows some similarities to adakites (Martin, 1999) and to recently described Neoarchean Closepet-granites (Moyen et al., 2001).

Interpretation of the geochemistry of sanukitoids is controversial. High $\mathrm{Mg} \#, \mathrm{MgO}, \mathrm{Ni}$ and $\mathrm{Cr}$ implies that sanukitoids are mantle-derived rocks, but high $\mathrm{Sr}, \mathrm{Ba}$ and LREE suggest crustal origin (Stern \& Hanson, 1991). These aspects of sanukitoid geochemistry have been explained with a two-stage process, which includes Archean subduction. In the first stage, melts and/or fluids derived from a subducting basaltic slab enriched the overlying mantle wedge with $\mathrm{Sr}, \mathrm{Ba}$ and LREE. Later melting of the enriched mantle generated sanukitoid magmas (Stern \& Hanson, 1991; Kovalenko et al., 2005). Pb isotopic studies indicate that subducted sediments may also have played an important role in the sanukitoid petrogenesis (Halla, 2005). Sanukitoids might thus be the first sign of existence of an enriched mantle wedge and the beginning of the modern style of plate tectonics (Martin \& Moyen, 2005).

Sanukitoids have been found in many Archean cratons and most of them are $-2.7 \mathrm{Ga}$ in age (Rollinson \& Martin, 2005). The -3.0 Ga sanukitoids from the Ukrainian Shield (Artemenko et al., 2003), the 


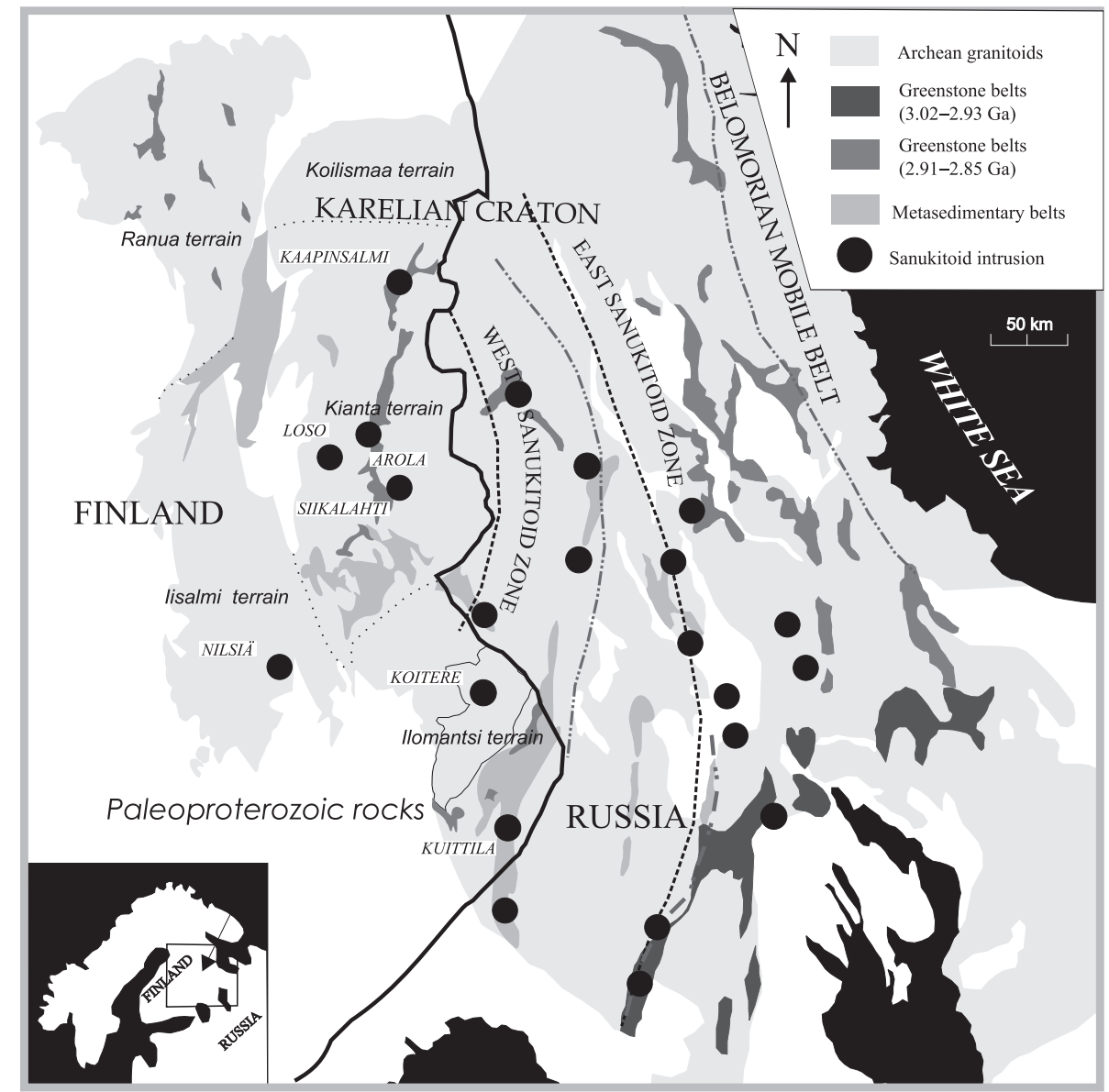

Fig. I. Geological map of the Karelian craton and sanukitoid intrusions. Sanukitoid zones and Russian sanukitoids are from Lobach-Zhuchenko et al. (2005); Loso, Arola and Siikalahti sanukitoids are from Käpyaho et al. (2006); and Koitere and Nilsiä sanukitoids are from Halla (2005). General features of the map according to Koistinen et al. (200I) and Sorjonen-Ward \& Luukkonen (2005).

-2.9 Ga sanukitoids from the Pilbara craton (Smithies \& Champion, 2000), and the -2.89 Ga sanukitoids from the Amazonian craton (Oliveira et al., 2006) are the only sanukitoid intrusions known to be older than $-2.7 \mathrm{Ga}$.

More than 20 sanukitoid intrusions have been found in the Karelian craton. Sanukitoid intrusions in the Russian part of the Karelian craton are divided into Eastern and Western sanukitoid zones, which differ in composition and age (Lobach-Zhuchenko et al., 2005; Bibikova et al., 2005). Seven sanukitoid intrusions located in Finland have been described:
Kuittila (O’Brien et al., 1993), Nilsiä, Koitere (Halla, 2005), Arola, Loso, Siikalahti (Käpyaho et al., 2006; Käpyaho 2006) and the recently recognised Kaapinsalmi sanukitoid intrusion (Heilimo, 2006a; 2006b) (Fig. 1). This paper describes in more detail the petrology of the Kaapinsalmi sanukitoid intrusion.

\section{Geological setting}

The Kaapinsalmi sanukitoid intrusion is located in Suomussalmi, in the Kianta terrain on the western margin of the Archean Karelian craton (Fig. 1). The 


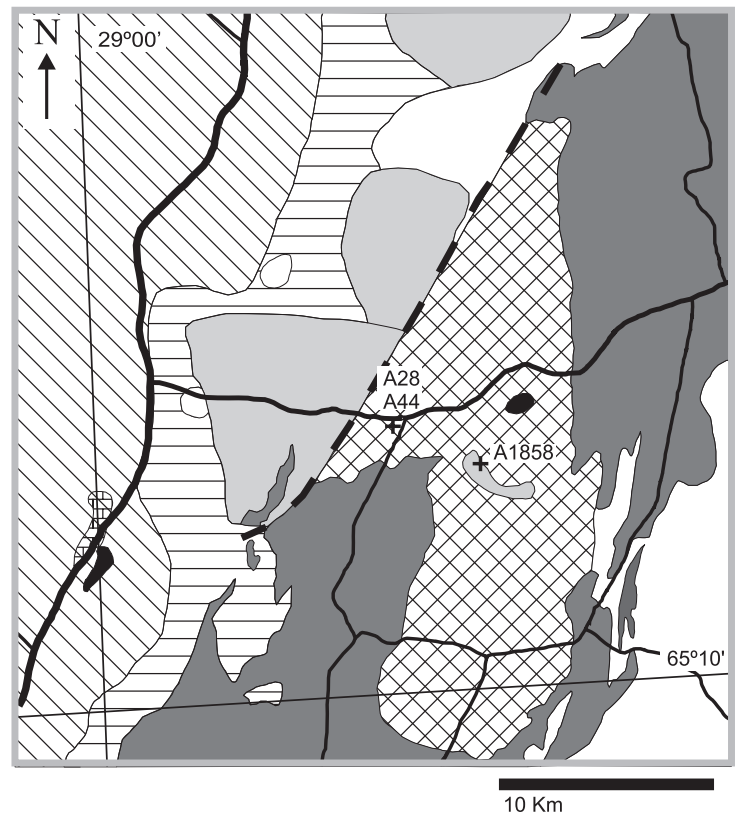

\begin{tabular}{|lc|}
\hline Kaapinsalmi sanukitoid & $\square$ Leucocratic granite and granodiorite \\
$\square$ Tonalite & $\square$ Migmatitic tonalitegneiss \\
$\square$ Suomussalmi greenstone belt & $\square$ Transition zone between migmatitic \\
$\square$ Pegmatite & gneiss and granitoids \\
'Sheared contact & $\square$ Ultramafite
\end{tabular}

Fig. 2. Geological map of the Kaapinsalmi area, showing the locations of the dated samples. The greenstone belt is modified from Sorjonen-Ward \& Luukkonen (2005).

Kianta terrain is a granite-greenstone terrain consisting mostly of migmatitic gneisses, greenstone belts, paragneisses and granitoids (Sorjonen-Ward \& Luukkonen, 2005). Migmatitic Päivärinta gneiss in the vicinity of Kaapinsalmi has mesosome aged 2.83 $2.84 \mathrm{Ga}$ and leucosome aged between $2.70-2.67 \mathrm{Ga}$ (Käpyaho et al., 2007). Greenstone belts in the Kianta terrain have been tectonically segregated into $\mathrm{Ti}$ pasjärvi, Kuhmo, and Suomussalmi greenstone belts. The ages of the greenstone belts are between -2.80 - 2.83 Ga (Luukkonen, 1992). Nurmes-type paragneisses in the Kianta terrain evidently have protolith ages as young as $-2.71-2.69 \mathrm{Ga}$ (Kontinen et al., 2007). Granitoids of the Kianta terrain are metamorphosed, but they have preserved their magmatic texture. Käpyaho et al. (2006) and Käpyaho (2006) have divided the Kianta granitoids into three magmatic episodes: 1) TTG-granitoids $2.83-2.74 \mathrm{Ga}, 2)$ sanukitoids $2.74-2.70 \mathrm{Ga}$ and 3) leucocratic granites and granodiorites $2.70-2.68 \mathrm{Ga}$.

The Kaapinsalmi sanukitoid lies adjacent to the western margin of the Suomussalmi greenstone belt (Fig. 2). It has intrusive contacts with the greenstone belt and contains greenstone xenoliths, contacts with granitoids are sheared and no contact has been observed with migmatitic gneisses. Within the Kaapinsalmi sanukitoid there is a small, brecciating intrusion of leucogranodiorite called Kivilahti. The Kaapinsalmi sanukitoid is mineralogically tonalite and also contains melatonalite inclusions. The texture of the Kaapinsalmi sanukitoid is granular and mortar. The major minerals are plagioclase, quartz, hornblende and biotite, while accessory minerals include microcline, sphene, allanite, apatite, zircon and opaque minerals. The secondary minerals are biotite, epidote, sericite, saussurite, chlorite and carbonate.

\section{Geochemistry}

The Kaapinsalmi sanukitoid and melatonalite inclusions display distinct sanukitoid characteristics: low $\mathrm{SiO}_{2}$ and high $\mathrm{Mg} \#, \mathrm{MgO}, \mathrm{Ni}, \mathrm{Cr}$ (Fig. 3). The Kaapinsalmi sanukitoid is intermediate $\left(\mathrm{SiO}_{2} 56.0\right.$ - $66.8 \%)$ and has high $\mathrm{Mg \#}(51.3$ - 64.2). There is a $2.8-7.4 \%$ variation in $\mathrm{MgO}$, while $\mathrm{Ni}$ and $\mathrm{Cr}$ abundances are greater compared to eastern Finland TTGs. The $\mathrm{K}_{2} \mathrm{O}$ content of the Kaapinsalmi sanukitoid is $0.8-2.7 \%$, while $\mathrm{Sr}$ varies between $206 \mathrm{ppm}$ and $643 \mathrm{ppm}$ and $\mathrm{Ba}$ from $316 \mathrm{ppm}$ to $1366 \mathrm{ppm}$. Melatonalite inclusions of the Kaapinsalmi sanukitoid have slightly higher $\mathrm{Mg} \#$ and higher contents of $\mathrm{MgO}, \mathrm{Ni}$ and $\mathrm{Cr}$ than the Kaapinsalmi sanukitoid, with $\mathrm{Cr}$ abundances of up to $626 \mathrm{ppm}$ and $\mathrm{Ni}$ abundances of up to $221 \mathrm{ppm}$; respective numbers for the Kaapinsalmi sanukitoid are 408 ppm and 207 ppm. The Kaapinsalmi sanukitoid and inclusions both have fractioned REE patterns with higher HREE than average eastern Finland TTG. Average $(\mathrm{La} / \mathrm{Lu})_{n}$ for the Kaapinsalmi sanukitoid is 21.2 and for the melatonalite inclusions 12.2 (Fig. 4). 

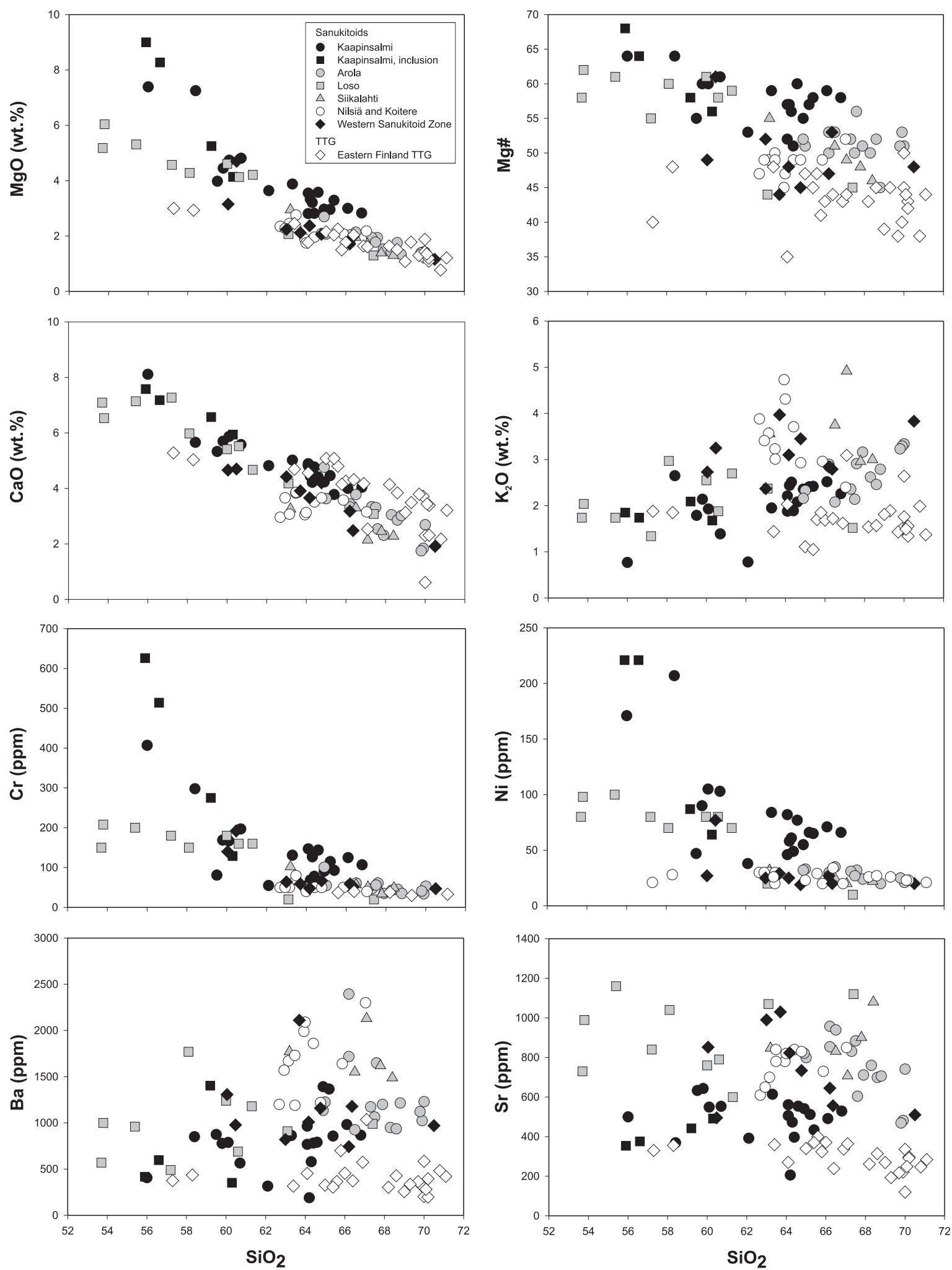

Fig. 3. Selected Harker diagrams illustrating geochemistry of West Karelian craton sanukitoids and TTGs. Data for Kaapinsalmi sanukitoid is from Heilimo (2006b); Arola, Loso, Siikalahti sanukitoids and Eastern Finland TTG data from Käpyaho (2006); data for Nilsiä and Koitere sanukitoids from Halla (2005) and that for Western sanukitoid zone is from Lobach-Zhuchenko et al. (2005). 


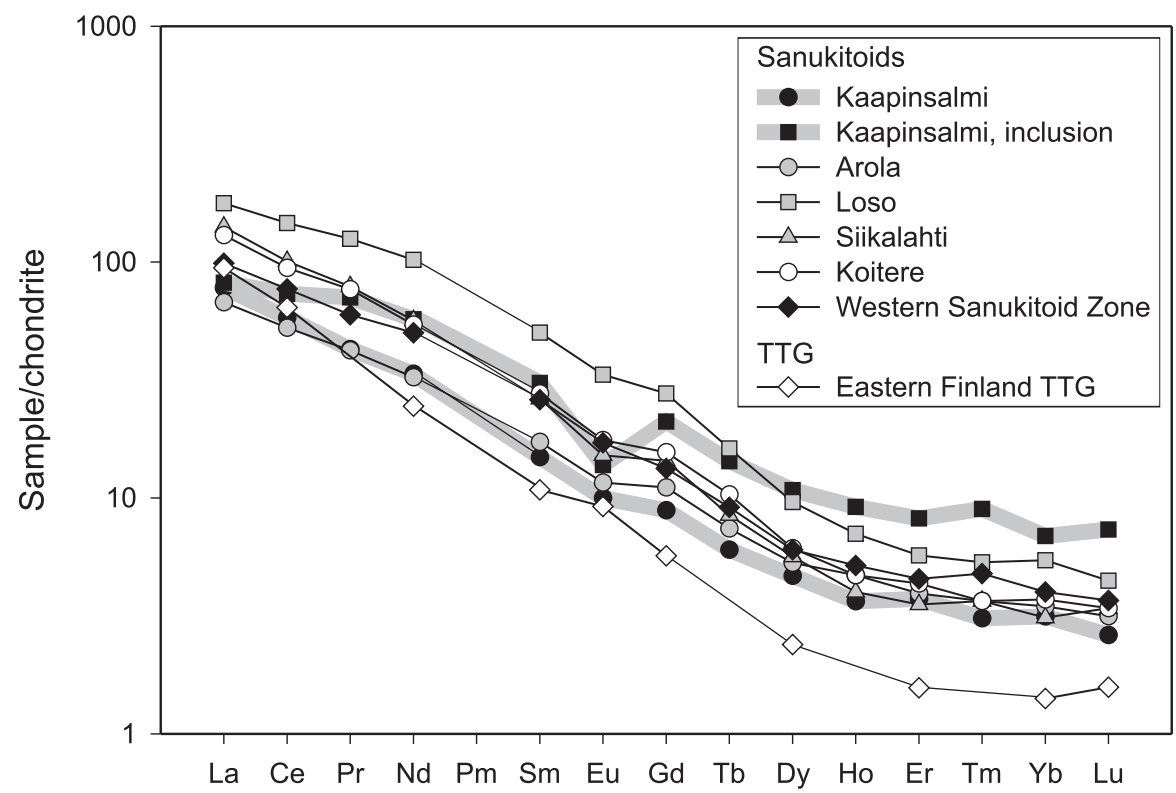

Fig. 4. Representative chondrite normalised REE-patterns of West Karelian craton sanukitoids and Eastern Finland TTG (normalisation values from Taylor \& McLennan, 1985). Kaapinsalmi sanukitoid data from Heilimo (2006b);Arola, Loso, Siikalahti sanukitoids analyses after Käpyaho (2006); Nilsiä and Koitere data from Halla (2005); Western sanukitoid zone data from Lobach-Zhuchenko et al. (2005) and Eastern Finland TTG patterns after Martin (1987).

\section{U-Pb dating methods}

Two samples from the Kaapinsalmi sanukitoid were collected for U-Pb dating (A28 by Eero Pehkonen and A44 by Erkki Luukkonen, see Fig. 2). U$\mathrm{Pb}$ samples were treated with methods described by Vaasjoki (2001) in 1978 and 1981 by Olavi Kouvo and staff of the isotopic laboratory of Geological Survey of Finland. Samples were washed, crushed and sorted on a wet shaking table and then treated with heavy liquids (bromofrom and Clerici ${ }^{\mathrm{TM}}$ ) and a Frantz magnetic separator. Zircon and sphene grains were selected for analysis by handpicking. $\mathrm{U}$ and $\mathrm{Pb}$ multigrain analyses were done using Krogh's method (1973). ${ }^{235} \mathrm{U}^{208} \mathrm{~Pb}$-spiked and unspiked isotopic rations were measured using thermal ionisation single collector mass spectrometer (TIMS) at the isotopic laboratory of Geological Survey of Finland, Espoo. $\mathrm{U}-\mathrm{Pb}$ calculations were done with PbDat (Ludwig, 1991) and IsoPlot/Ex (Ludwig, 2003) programs.

\section{U-Pb dating results}

Zircons from the Kaapinsalmi sanukitoid were light brown and translucent in the heavy fraction. Crystal shapes were pyramidic and prismatic from subhedral to euhedral. Sample A28A was originally analysed by Kouvo \& Tilton (1966) using old borax method and the resulting ${ }^{207} \mathrm{~Pb} /{ }^{206} \mathrm{~Pb}$ age was $2681 \mathrm{Ma}$. Afterwards, three discordant zircon fractions from sample A28 were analysed producing an upper intersect at $2718 \pm 6 \mathrm{Ma}$. Additional sample A44 gave an upper intersect at $2719 \pm 4 \mathrm{Ma}$, with two discordant zircon fractions and an almost concordant sphene fraction. Both ages are same within the error limits. A combined age of $2716 \pm 9$ Ma from both samples (A28 \& A44) is thus a relatively good estimate of the Kaapinsalmi sanukitoid intrusion age (Fig. 5, Table 1).

Kivilahti leucogranodiorite located inside the Kaapinsalmi sanukitoid was also sampled (A1858) (see Fig. 2) for U-Pb dating. However, separation did not produce enough zircon or monazite for TIMS analysis. 


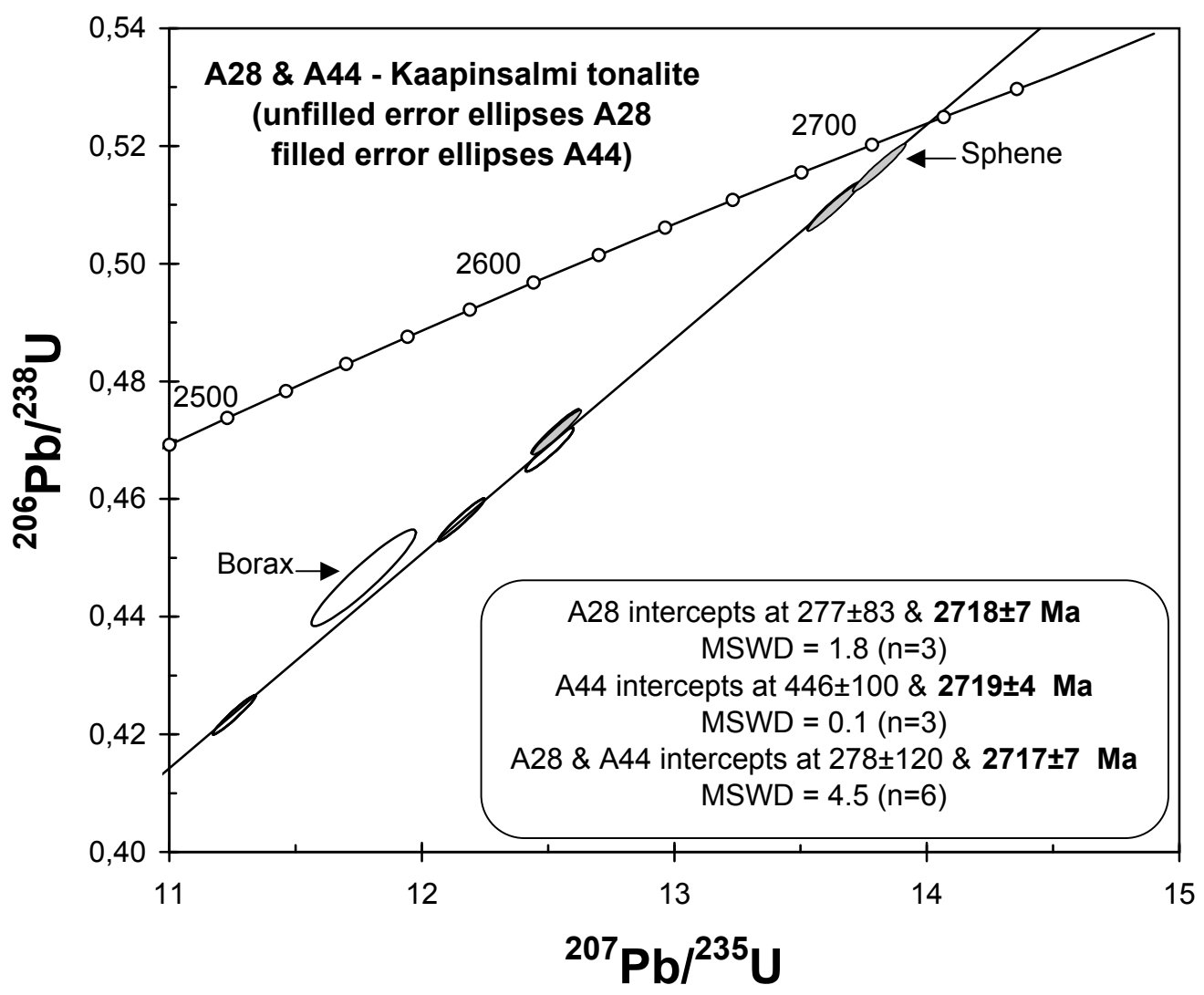

Fig. 5. Concordia diagram showing U-Pb isotopic data for the Kaapinsalmi sanukitoid. A28 fractions are unfilled error ellipses and A44 fractions are filled error ellipses. A44C sphene U-Pb isotopic data is included and A28A borax $\mathrm{U}-\mathrm{Pb}$ isotopic data is excluded from the geochron (Kouvo and Tilton, 1966).

\section{Discussion}

In the Karelian craton, sanukitoids are younger than the surrounding TTG, implying that sanukitoids are not directly linked to the subduction processes that might have produced TTGs (Bibikova et al., 2005). The sanukitoid intrusions of the Russian part of the Karelian craton are divided into Eastern and Western sanukitoid zones (Lobach-Zhuchenko et al., 2005; Bibikova et al., 2005). The sanukitoid intrusions in the Eastern sanukitoid zone were formed 2.730 - 2.745 Ga ago. They are more mafic in composition, with higher $\mathrm{MgO}, \mathrm{Ni}, \mathrm{Cr}$ and lower $\mathrm{Ba}$, Sr compared to the Western sanukitoid zone intrusions. The Eastern sanukitoid zone also shows more heteroge- neity and a larger mantle-derived component than the Western sanukitoid zone. The Western sanukitoid zone is younger, with intrusions in the age range $2.700-2.720 \mathrm{Ga}$.

Location, age $(-2.72 \mathrm{Ga})$ and composition of the Kaapinsalmi sanukitoid all show certain similarities to the Western sanukitoid zone (Figs. 1, $3 \& 4$ ), although the $\mathrm{Mg} \#, \mathrm{MgO}, \mathrm{Ni}$ and $\mathrm{Cr}$ contents of the Kaapinsalmi sanukitoid are higher at their respective $\mathrm{SiO}_{2}$ level than in the other west Karelian sanukitoids (Fig. 4). The Kaapinsalmi sanukitoid also has relatively low $\mathrm{Ba}$ and $\mathrm{Sr}$ contents when compared to those of the Western sanukitoid zone and other Finnish sanukitoids. Comparatively low $\mathrm{K}_{2} \mathrm{O}, \mathrm{Ba}, \mathrm{Sr}$ and 


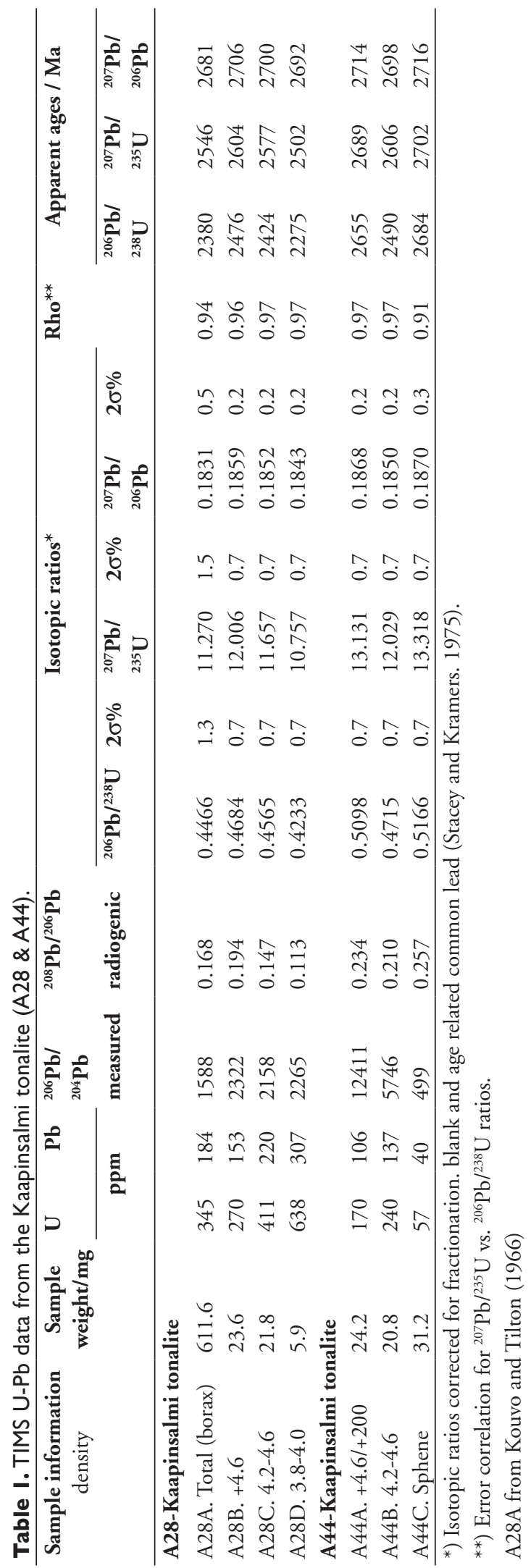

high $\mathrm{MgO}, \mathrm{Ni}, \mathrm{Cr}$ contents make the Kaapinsalmi sanukitoid a distinct sanukitoid in western part of the Karelian craton. The Rio Maria sanukitoid, located in the Amazonian craton in Brazil (Oliveira et al., 2006), is similar in composition to the Kaapinsalmi sanukitoid.

Current models for the petrogenesis of sanukitoids propose that fluids and/or melts from subducted basaltic slab and possible sediments enriched the overlying mantle wedge. Subsequent melting of the enriched mantle wedge then formed the sanukitoid magmas. Sanukitoids thus might contain material from three different sources: basaltic slab, sediments and mantle wedge (Stern \& Hanson, 1991; Kovalenko et al., 2005; Halla, 2005). A probable source of $\mathrm{MgO}, \mathrm{Ni}$ and $\mathrm{Cr}$ is the mantle wedge; and of $\mathrm{K}_{2} \mathrm{O}$, $\mathrm{Ba}$ and $\mathrm{Sr}$ the slab melts and/or fluids from a crustal component, possibly subducted sediments.

There are two possible explanations for the distinct composition of the Kaapinsalmi type sanukitoid: 1) Less involvement of recycled crust in the petrogenesis of the Kaapinsalmi type sanukitoid. This could explain the lower $\mathrm{K}_{2} \mathrm{O}$, Sr and $\mathrm{Ba}$ contents and higher $\mathrm{MgO}$, Ni and $\mathrm{Cr}$ content. 2) Heterogeneity in the enrichment of the mantle wedge could also explain the composition of Kaapinsalmi type sanukitoid. If fluids and/or melts from the basaltic slab and possible sediments infiltrated the mantle wedge in an irregular manner, then partial melting of the less enriched parts of the wedge would have caused Kaapinsalmi type sanukitoid magmas. These two explanations are not mutually exclusive and could occur simultaneously.

\section{Conclusions}

The newly-recognised Kaapinsalmi intrusion has chemical composition similar to sanukitoid. Its age, location and certain compositional similarities indicate that it forms the northern extension of the Western sanukitoid zone of the Karelian craton. However, there are two important geochemical differences between the Kaapinsalmi sanukitoid and with other West Karelian sanukitoids: 
1. The Kaapinsalmi sanukitoid has lower $\mathrm{SiO}_{2}$ and higher $\mathrm{MgO}, \mathrm{Ni}$, and $\mathrm{Cr}$ contents compared to those of the other west Karelian sanukitoids, indicating that the primary source of the Kaapinsalmi sanukitoid was mantle peridotite.

2. The Kaapinsalmi sanukitoid has relatively low $\mathrm{K}_{2} \mathrm{O}, \mathrm{Ba}$, and $\mathrm{Sr}$ concentrations. This might indicate smaller recycled crustal sediment component in the source of the Kaapinsalmi sanukitoid than in more felsic sanukitoids and/or mantle heterogeneity.

\section{Acknowledgements}

We would like to thank journal referee Svetlana Lobach-Zhuchenko for thoughtful review of the manuscript. Olavi Kouvo and staff of the isotopic laboratory of Geological Survey of Finland are acknowledged for isotopic determinations. Peter Sorjonen-Ward is thanked for comments and reviewing the language and Mikko Pitkänen for reviewing the language. This work was done as part of the GSF's regional bedrock mapping in the Suomussalmi area.

\section{References}

Artemenko, G.V., Lobach-Zhuchenko, S.B., Krylov, I.N. \& Orsa, V.I., 2003. Archean high-Mg granitoids (sanukitoids) in the Ukrainian Shield and its comparison with rocks of TTG suite. Geophysical Research Abstracts 5. Abstracts of the Contributions of the EGS-AGU-EUG Joint Assembly, Nice, France, 06-11 April, 2003. European Geophysical Society (CD-ROM).

Bibikova, E.V., Petrova, A. \& Claesson, S., 2005. The temporal evolution of sanukitoids in the Karelian craton, Baltic Shield: an ion microprobe $\mathrm{U}-\mathrm{Th}-\mathrm{Pb}$ isotopic study of zircons. Lithos 79, 129-145.

Halla, J., 2005. Late Archean high-Mg granitoids (sanukitoids) in the Southern Karelian domain, Eastern Finland. Lithos 79, 161-178.

Heilimo, E., 2006a. Petrography and geochemistry of the Kaapinsalmi 2.72 Ga Sanukitoid intrusion, Eastern Finland. Bulletin of the Geological Society of Finland, Special Issue 1, p. 47.

Heilimo, E., 2006b. Kaapinsalmen sanukitoidin ja sitä ympäröivien granitoidien petrologia ja geokemia. Unpublished M.Sc. Thesis (available at request from the author), University of Helsinki, Finland, 62 p.

Koistinen, T., Stephens, M.B., Bogatchev, V., Nordgulen, Ø., Wennerström, M. \& Korhonen, J., (eds.), 2001. Geological map of the Fennoscandian Shield, scale
1:2 000 000. Geological Surveys of Finland, Norway, Sweden and the North-West department of Natural Resources of Russia.

Kontinen, A., Käpyaho, A., Huhma, H., Karhu, J., Matukov, D.I., Larionov, A. \& Sergeev, S.A., 2007. Nurmes paragneisses in Eastern Finland, Karelian craton: Provenance, tectonic setting and implications for Neoarchaean craton correlation. Precambrian Research 152, 119148.

Kouvo, O. \& Tilton, G., 1966. Mineral ages from the Finnish Precambrian. Journal of Geology 74, 421-442.

Kovalenko, A., Clemens, J.D. \& Savatenkov, V., 2005. Petrogenetic constraints for the genesis of Archaean sanukitoid suites: geochemistry and isotopic evidence from Karelia, Baltic Shield. Lithos 79, 147-160.

Krogh, T.E., 1973. A low-contamination method for hydrothermal decomposition of zircon and extraction of $\mathrm{U}$ and $\mathrm{Pb}$ for isotopic age determinations. Geochimica et Cosmochimica Acta 37, 485-494.

Käpyaho, A., 2006. Whole-rock geochemistry of some tonalite and high $\mathrm{Mg} / \mathrm{Fe}$ gabbro, diorite, and granodiorite plutons (sanukitoid suite) in the Kuhmo district, Eastern Finland. Bulletin of the Geological Society of Finland 78, 121-141.

Käpyaho, A. Mänttäri, I. \& Huhma, H., 2006. Growth of Archaean crust in the Kuhmo district, Eastern Finland: $\mathrm{U}-\mathrm{Pb}$ and $\mathrm{Sm}-\mathrm{Nd}$ isotope constraints on plutonic rocks. Precambrian Research 146, 95-119.

Käpyaho, A., Hölttä, P. \& Whitehouse J.W. 2007. U-Pb zircon geochronology of selected Neoarchaean migmatites in eastern Finland. Bulletin of the Geological Society of Finland 79, 95-115.

Lobach-Zhuchenko, S.B., Rollinson, H.R., Chekulaev, V.P., Arestova, N.A., Kovalenko, A.V., Ivanikov, V.V., Guseva, N.S., Sergeev, S.A., Matukov, D.I. \& Jarvis, K.E., 2005. The Archaean sanukitoid series of the Baltic Shield: geological setting, geochemical characteristics and implication for their origin. Lithos 79, 107-128.

Ludwig, K.R., 1991. PbDat 1.21 for MS-dos: A computer program for processing $\mathrm{Pb}-\mathrm{U}-\mathrm{Th}$ isotope data. Version 1.08. U.S. Geological Survey Open-File Report 88$542,35 \mathrm{p}$.

Ludwig, K.R., 2003. Isoplot/Ex 3. A Geochronological Toolkit for Microsoft Excel. Berkeley Geochronologicy Center, Special Publication No. 4.

Luukkonen, E.J., 1992. Late Archean and early Proterozoic structural evolution in the Kuhmo-Suomussalmi terrain, Eastern Finland. Annales Universitatis Turkuensis. SarjaSer. A.II. Biologica-Geographica-Geologica 78, 113 p.

Martin, H., 1987. Petrogenesis of of Archaean trondhjemites, tonalites, and granodiorites from Eastern Finland: Major and trace elements geochemistry. Journal of Petrology, 28, 921-953.

Martin, H., 1999. Adakitic magmas: modern analogues of Archaean granitoids. Lithos 46, 411-429. 
Martin, H. \& Moyen, J.-F., 2005. The Archaean-Proterozoic transition: Sanukitoid and Closepet type magmatism. Mineralogical Society of Poland - Special papers Volume 26, 57-68.

Moyen, J.-F., Martin, H. \& Jayananda, M., 2001. Multi-element geochemical modeling of crust-mantle interactions during late-Arhaean crustal growth: the Closepet granite (South Indian). Precambrian Research 112, 87-105.

O’Brien, H., Huhma, H. \& Sorjonen-Ward, P., 1993. Petrogenesis of the late Archean Hattu Shist belt, Ilomantsi, Eastern Finland: geochemistry and $\mathrm{Sr}$, $\mathrm{Nd}$ isotopic composition. Geological Survey of Finland, Special Paper 17, 147-184.

Oliveira, M.A., Dall'Agnol, R. \& Althoff, F.J., 2006. Petrography and geochemistry of the Archean sanukitoid Rio Maria granodiorite and mafic rocks associated, Rio Maria granite-greenstone terrane, Amazon craton. In: Dall'Agnol, R., Rosa-Costa, L.T. \& Klein, E.L. (eds.) Symposium on magmatism, crustal evolution, and metallogenesis of the Amazonian craton. Abstracts volume and field trips guide. Belém, PRONEX-UFPA/SBG-NO, p. 29.

Rollinson, H. \& Martin, H., 2005. Geodynamic controls on adakite, TTG and sanukitoid genesis: implications for models of crust formation Introduction to the Special Issue. Lithos 79, ix-xii.

Shirey, S.B. \& Hanson, G.N., 1984. Mantle-derived Archaean monzodiorites and trachyandesites. Nature 310, 222-224.

Sorjonen-Ward, P. \& Luukkonen, E.J., 2005. Archean rocks. In: Lehtinen M., Nurmi, P.A. \& Rämö, O.T. (eds.) Precambrian Geology of Finland - Key to the evolution of the Fennoscandian shield. Developments in Precambrian Geology 14, Elsevier, Amsterdam, pp. 19-100.

Smithies, R.H. \& Champion, D.C., 2000. The Archaean high- $\mathrm{Mg}$ diorite suite: links to tonalite-trondhjemitegranodiorite magmatism and implications for early Archaean crustal growth. Journal of Petrology 41, 16531671.

Taylor, S.R. \& McLennan, S.M., 1985. The continental crust: its composition and evolution. Blackwell, Oxford, 312 p.

Stacey, J.S. \& Kramers, J.D., 1975. Approximation of terrestrial lead isotope evolution by two-stage model. Earth and Planetary Science Letters 26, 207-221.

Stern, R.A., Hanson, G.N. \& Shirey, S.B., 1989. Petrogenenesis of mantle-derived, LILE-enriched Archean monzodiorites and trachyandesites (sanukitoids) in southwestern Superior Province. Canadian Journal of Earth Science 26, 1688-1712.

Stern, R.A. \& Hanson, G.N., 1991. Archaean high-Mg granodiorite: a derivative of light rare earth elementenriched monzodiorite of mantle origin. Journal of Petrology 32, 201-238.

Vaasjoki, M., 2001. Three decades of U-Pb mineral anal- yses at the Geological Survey of Finland. In: Vaasjoki, M. (ed.) Radiometric age determinations from Finnish Lapland and their bearing on the timing of Precambrian volcano-sedimentary sequences. Geological Survey of Finland, Special Paper 33, 9-13. 